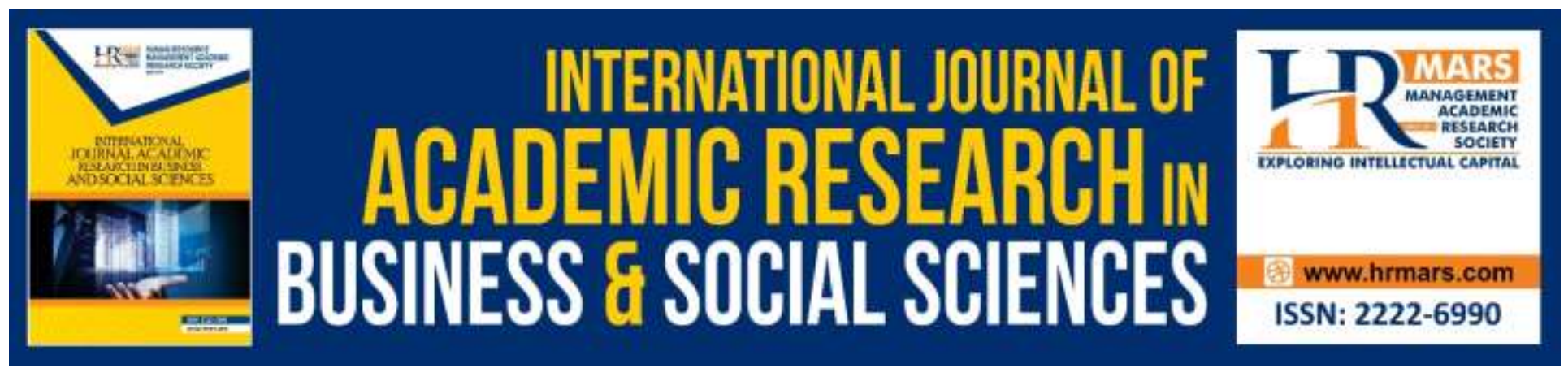

\title{
Social Enterprises' Performance: The Influences of Corporate Structure, Corporate Monitoring Process and Corporate Controlling Process
}

Razana Juhaida Johari, Zuraidah Mohd Sanusi \& Nur Aima Shafei

To Link this Article: http://dx.doi.org/10.6007/IJARBSS/v10-i13/6890 ～DOI:10.6007/IJARBSS/v10-i13/6890

Received: 10 December 2019, Revised: 07 January 2020, Accepted: 22 January 2020

Published Online: 09 February 2020

In-Text Citation: (Johari et al., 2020)

To Cite this Article: Johari, R. J., Sanusi, Z. M., \& Shafei, N. A. (2020). Social Enterprises' Performance: The Influences of Corporate Structure, Corporate Monitoring Process and Corporate Controlling Process. International Journal of Academic Research in Business and Social Sciences, 10(13), 73-87.

Copyright: (C) 2020 The Author(s)

Published by Human Resource Management Academic Research Society (www.hrmars.com)

This article is published under the Creative Commons Attribution (CC BY 4.0) license. Anyone may reproduce, distribute, translate and create derivative works of this article (for both commercial and non-commercial purposes), subject to full attribution to the original publication and authors. The full terms of this license may be seen

at: $\underline{\text { http://creativecommons.org/licences/by/4.0/legalcode }}$

Special Issue: Upstream Research in Business and Management: Towards Socio-Economic Prosperity, 2020, Pg. 73 - 87

http://hrmars.com/index.php/pages/detail/IJARBSS

JOURNAL HOMEPAGE

Full Terms \& Conditions of access and use can be found at

http://hrmars.com/index.php/pages/detail/publication-ethics 


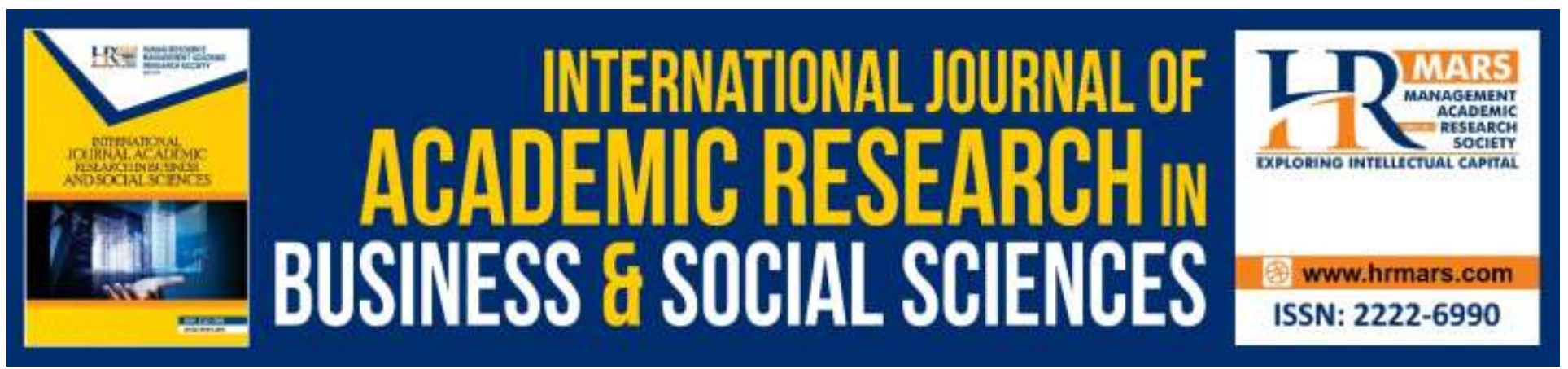

\title{
Social Enterprises' Performance: The Influences of Corporate Structure, Corporate Monitoring Process and Corporate Controlling Process
}

\author{
Razana Juhaida Johari, Zuraidah Mohd Sanusi \& Nur Aima Shafei \\ Faculty of Accountancy, UiTM Shah Alam, Malaysia
}

\begin{abstract}
Social enterprises refer to enterprises which develop, fund and incorporate solutions that positively impact the social, cultural and environmental issues. The introduction of Malaysia Social Enterprise Blueprint which actively promotes various social enterprises initiatives showed the support from the Malaysian government on the social enterprises. However, despite the attention given on the benefits that could be delivered through the social enterprises, public at large are questioning the issues on corporate governance practices and performance of social enterprises. Thus, this study aims to examine the relationship between the corporate governance practices and performance of social enterprises in Malaysia. Corporate governance practices are vital as carefully selected, well-designed and well-managed governance will help to improve the performance of social enterprises. There are three components of corporate governance practices examined in this study namely corporate structure, corporate monitoring process and corporate controlling process. Meanwhile, the performance of social enterprises is measured from the perspectives of social value and financial value. This study is based on the data obtained from 86 selected social enterprises established in Malaysia and registered with Company Commission of Malaysia. The results indicate that only corporate monitoring process has a positive relationship with social value while corporate structure has a positive relationship to both of the social value and financial value. It is hoped that the study can contribute to the improvement of performance of social enterprises in Malaysia and as well as encourage development of research in the area of social enterprises.
\end{abstract}

Keywords: Social Enterprises, Social Value, Financial Value, Corporate Structure, Corporate Monitoring Process, Corporate Controlling Process

\section{Introduction}

The growth in the number and importance of the social enterprise sector has begun to raise new concerns about the governance of social enterprises (Low, 2006). Similar with other forms of business, social enterprise are also exposed to the risk of fraud, bankruptcies and business failures 
INTERNATIONAL JOURNAL OF ACADEMIC RESEARCH IN BUSINESS AND SOCIAL SCIENCES

Vol. 10, No. 13, Special Issue: Upstream Research in Business and Management: Towards Socio-Economic Prosperity. 2020, E-ISSN: 2222-6990 @ 2020 HRMARS

(Spear, Cornforth, \& Aiken, 2009). Low (2006) noted that corporate governance is a crucial part of the social enterprises' management. A well incorporated governance would help in safeguarding the mission of the social enterprise, allowing the management team to meet the demands of variety stakeholders (Crucke \& Decramer, 2016; Tyasari, Yusof, Bahador, 2018) and establish rules that can help in monitoring and controlling the management systems (Bhatt \& Bhatt, 2017). Therefore, it is seen that an implementation of proper governance would bring positive impact on the performance of the social enterprises. Crucke and Decramer (2016) defined social enterprise as a social missiondriven organization that conduct an entrepreneurial activity of selling goods or providing services with the intention of satisfying the social needs. According to Marthin and Thompson (2010), the conceptual and definition of social enterprises are still largely unresolved and remained vague. There are many different definitions of social enterprise exists. However, there are two characteristics that exist in each of these definitions which are 'social impact' and 'trading'. Therefore, it can be summarized that social enterprise is primarily concerned on creating social value through the business activities of selling goods or providing services to the community.

In Malaysia, the practice of providing social services to the community has been around for years but only in recent years the concept of social enterprise is increasingly getting more interest from practitioners, academics and policy makers (Bahari \& Suhaimi, 2016; Sidek, Mobidin, \& Adam, 2018). The concept of social enterprise has created global interests over the decade (Rizam, Abdullah, \& Abdulsomad, 2017). According to Son, Lee and Chung (2017), the growth in the attention towards social enterprise is due to an effort of resolving complex social problems and securing the sustainability of society. Son et al. (2017) also stated that an increasing number of social enterprises have recently emerged in many different countries in an attempt to deal with social issues such as unemployment, disease, poverty and lack of education among those experiencing extreme poverty.

Currently, there is an increasing agreement that the social enterprises should develop performance measurement (Crucke \& Decramer, 2016) that reflect on both social value and financial value as the main mission of social enterprises is to create social value and deal social problems while ensure financial sustainability. Crucke and Decramer ( 2016) identified ggovernance performance as one of the performance domains in measuring the performance of the social enterprises. The authors further described that governance performance is certainly an important indicator as it is predicted that good governance practices would bring positive impact on the overall performance of the social enterprises. The corporate governance practice involves the process of setting the structure, monitoring and controlling the operation of the organization.

The process of setting the corporate structure emphasizes effort to ensure that the necessary resources are in place for the organization to meet its objectives and review performance (MCCG, 2017). Through the monitoring process, it enables the organization to improve their performance and wider its impact to the various stakeholder (Lipiper, Lajh, \& Gric, 2013). Other than that, effective monitoring can bring down the agency costs, thereby improving the firm performance (Pitcher et al., 2000; Eisenhardt, 1989; Strebel, 2004; Conyon and Peck, 1998; Vrettou, 2014). Next, according to Merwe (2011), controlling is an essential part in managing the operations and review the performance of an organisation. It is claimed that the controlling process is closely related to the subordination between managers in discussing all problems and solutions, taking control of the entire business process and determining and managing all the uncertainties which can impact on the performance of the organisation (Eker \& Eker, 2016). 
INTERNATIONAL JOURNAL OF ACADEMIC RESEARCH IN BUSINESS AND SOCIAL SCIENCES

Vol. 10, No. 13, Special Issue: Upstream Research in Business and Management: Towards Socio-Economic Prosperity. 2020, E-ISSN: 2222-6990 @ 2020 HRMARS

Empirically, study on corporate governance pertaining to the performance of social enterprises has received minimal attention despite its growth in the number and importance. Specifically, research on the corporate governance practices and their effects on the performance particularly social enterprise registered as company limited by guarantee have received little observation (Low, 2006). This provides opportunity for the academics and researchers to further understand the corporate governance practices of the social enterprises and how these could affect the performance. In response to this concern, this study aims to examine the effect of the corporate governance practices (i.e. corporate monitoring process, corporate controlling process and corporate structure) on the social and financial value performance of social enterprises in Malaysia.

\section{Literature Review and Hypotheses Development Overview of Social Enterprises in Malaysia}

The concept of social enterprise is still new even though social enterprises have existed for many decades (Rizam, Abdullah, \& Abdulsomad, 2017). Although the Malaysian social enterprise sector is currently in the infant phase (Bahari \& Suhaimi, 2016), a variety of social enterprises already exists in Malaysia in the form of cooperatives, public enterprises or schools. The social enterprises in Malaysia are registered and governed by various legislations. Most of the social enterprises are registered with Companies Commission of Malaysia (CCM), Cooperative Commission of Malaysia and Registry of Societies Malaysia (ROS). For the social enterprises that have at least RM1 million revenue or more, it is registered with CCM as the companies limited by guarantee (CLBG) and governed by the Companies Act 2016. In 2017, there are 500 social enterprises registered and governed by CCM as CLBG. Meanwhile, for the social enterprises with less than RM1 million revenue is registered with ROS and governed by the Societies Act of 1966 and for the social enterprises registered with Cooperative Commission of Malaysia, it is governed by the Cooperative Societies Act 1993. In addition, the social enterprise sector has been increasingly recognised and received support by the government. The effort for promoting social enterprises was introduced by the cabinet in 2013 (Rizam, Abdullah, \& Abdulsomad, 2017). This can be proven through the introduction of several incentives to promote the development of social enterprises such as tax exemption, Malaysian Social Enterprise Blue Print 2015 and involvement of social enterprises in the National Key Results Areas (NKRAs) (Nizam, 2017).

\section{Performance Measurement of Social Enterprises}

There is an increasing agreement that the social enterprises should develop performance measurement (Crucke \& Decramer, 2016). The performance measurement could assist the social enterprises in responding to the increasing needs of accountability towards different stakeholders. The most important thing, the performance measurement of social enterprise must reflect both social and financial value as the aim of social enterprise is to create blended return on investment that integrate return of social, cultural, environmental and financial investment (Zainon et al, 2014; Elson \& Hall, 2012). It is noted that while financial performance plays an important role in a social enterprise, it is more essential in meeting the social mission of the organization (Bagnoli \& Megali, 2011). 
INTERNATIONAL JOURNAL OF ACADEMIC RESEARCH IN BUSINESS AND SOCIAL SCIENCES

Vol. 10, No. 13, Special Issue: Upstream Research in Business and Management: Towards Socio-Economic Prosperity. 2020, E-ISSN: 2222-6990 @) 2020 HRMARS

\section{Corporate Governance Practices of Social Enterprises}

In general, corporate governance is defined as the process and policies that directs the organization in the way they manage, monitor and control their business operations towards promoting business prosperity and corporate accountability (MCCG, 2017; Crucke \& Decramer, 2016). In Malaysia, due to the lacking of legal recognition as to what constitutes a social enterprise, social enterprises have been facing difficulties in choosing the right and suitable legal structure to register and operate their social activities (Mokhtar, Abdullah, \& Kin, 2014). As mentioned previously, Malaysian social enterprises can be registered and governed through various legislations. Therefore, the practice of corporate governance would be differing depending on the regulatory frameworks in which the social enterprise operates. Therefore, this study referred to both the MCCG and Corporate Governance of Cooperatives to view the guidelines of best governance practices that involves the process of setting the corporate structure, monitoring and controlling the operation of the organization.

\section{Relationship between Corporate Monitoring Process and Performance}

According to Lipiper, Lajh and Gric (2013), an organization could improve its performance by monitoring the operational and managerial procedure of the organization. The authors also stated that through monitoring, the organization is able to obtain information about the impacts of implementation of an activity towards the wider governance practices, transparency and human rights and wellbeing. An effective monitoring can bring down its agency costs, thus enhancing the firm performance. For instance, through the monitoring process, the construction companies are able to monitor and improve the current performance of the firm and as well as the project level. The information obtained from the monitoring process is also important for the top managers in dealing with the business risks, responding to the opportunities and planning strategies for the future. Therefore, it is anticipated that corporate monitoring process and performance in terms of social value and financial value of the social enterprises are positively related. Hence, the hypotheses are developed as follows:

$H 1$ (a): There is a positive effect of corporate monitoring process on social value of the social enterprises.

$H 1$ (b): There is a positive effect of corporate monitoring process on financial value of the social enterprises.

\section{Relationship between Corporate Controlling Process and Performance}

Controlling process is a process by which managers assist in the accomplishment of an organization's objectives by ensuring that the resources are used effectively and efficiently, thus resulting to the enhancement of the performance of the organization (Eker \& Eker, 2016). Thus, these controlling activities by the management are expected to enhance the performance of the organization. Fiskovi (2013) found that an effective controlling has positive effects on the companies' financial performance. His study revealed that the companies that conduct the controlling process have higher return on asset and return on equity than those companies without the controlling activities. Due to the lack of literature review on the controlling process and performance of the social enterprise, this study suggested that controlling process could give positive impact on the performance in terms of social value and financial value of the social enterprises and hence, the hypotheses are developed as follows: 
INTERNATIONAL JOURNAL OF ACADEMIC RESEARCH IN BUSINESS AND SOCIAL SCIENCES

Vol. 10, No. 13, Special Issue: Upstream Research in Business and Management: Towards Socio-Economic Prosperity. 2020, E-ISSN: 2222-6990 @ 2020 HRMARS

H2 (a): There is a positive effect of corporate controlling process on social value of the social enterprises.

H2 (b): There is a positive effect of corporate controlling process on financial value of the social enterprises.

\section{The Relationship between Corporate Structure and Performance}

Fadeyi (2016) examined the impact of corporate structure on the performance of the South African mining companies. The results of the study show that the board with diversity skills, knowledge and expertise are necessary for the companies' financial success. Other than that, the results found that the presence of the board of directors could increase the value of the companies and as well as enhance the financial results of the companies. Kallamu \& Saat (2015) also suggested that board of directors provide effective monitoring of the management thereby reducing possibility for opportunistic behaviour by the management and thus resulting to the improvement of performance of the companies. In addition, board of directors are responsible in providing access to various resources and strategic advice to help managers in achieving their profit maximization goals (Pugliese et al., 2009). These findings showed that corporate structure and performance in terms of social value and financial value of the social enterprises are positively related. Hence, the hypotheses are developed as follows:

$\mathrm{H3}(\mathrm{a})$ : There is a positive effect of corporate structure and social value of the social enterprises. H3 (b): There is a positive effect of corporate structure and financial value of the social enterprises.

\section{Method}

Research Design - Questionnaire were used as the research instrument of this study as it is a convenient way of collecting useful data (Surveys \& Guidelines, 2010). The questionnaire is distributed through electronic mail, Google forms, postal and personally to the Board of Trustee of selected social enterprises. The respondents are required to provide their agreement or disagreement on the corporate governance practices and performance of their organization.

Sample Selection - The population for this study is drawn from 500 social enterprises registered with Company Commission of Malaysia (CCM) as the company limited by guarantee (CLBG). 300 social enterprises were randomly selected as the sample size for this study (Yamane, 1967). The selection of this sample was based on the location of their business operation. The officer level (i.e. executive, manager and Board of Trustee) was selected as the respondents of this study due to the positions and responsibilities that they held in establishing appropriate policies of governance and operation, supervising the affairs of the organization and making financial decisions on behalf of the social enterprises.

Research Instrument and Variable Measurement - The questionnaires were designed to gather information about the corporate governance practices and performance of social enterprises. The questionnaire was structured using the Likert format with a seven-point response scale and consists of six sections comprising of closed-ended questions. The dependent variable consists of two variables which are social value and financial value with the adapted measurement items from Bagnoli and Megali (2011). The independent variables consist of corporate monitoring process, corporate controlling process and corporate structure used to measure the respondents' degree of 
INTERNATIONAL JOURNAL OF ACADEMIC RESEARCH IN BUSINESS AND SOCIAL SCIENCES

Vol. 10, No. 13, Special Issue: Upstream Research in Business and Management: Towards Socio-Economic Prosperity. 2020, E-ISSN: 2222-6990 @ 2020 HRMARS

agreement or disagreement to a list of statements. The items for all of the independent variables are adapted from the Halim, Mustika, Sari, Anugerah \& Sanusi (2017).

Data Collection - In order to achieve the research objective of this study, 300 set of introductory letter, questionnaires and stamped reply envelope were distributed through electronic mail, postal, Google forms and personally to the selected social enterprises. From the 300 set of questionnaires distributed, 86 were returned (28 percent response rate) and 214 were uncollectable due to no response.

\section{Results Analysis \\ Demographic Information}

From a total of 86 respondents, $30.2 \%$ of them were male and the $69.8 \%$ remaining respondents was female. For the age group, majority of the respondents were in the age ranging from 20 to 40 years old, which comprises of $72.1 \%$ of the respondents, $11.6 \%$ in the range of age between 41 to 50 years old and $16.3 \%$ in the range of age of 51 and above. In terms of ethnicity, the highest ethnicity is Malay which comprises of $69.8 \%$ followed by $16.3 \%$ of Chinese and lastly, $14.0 \%$ of the respondents are Indian. In terms of position, $60.5 .2 \%$ hold the position of executive, followed by $16.3 \%$ of manager and $23.2 \%$ Board of Trustee member. Majority of the respondents working with the enterprise for less than 10 years (79.1\%). For the financial resources, majority of the financial resources come from donation, which comprise of $54.7 \%$, followed by $24.4 \%$ income from grants, $18.6 \%$ income from business and lastly, 2.3\% from other sources. In terms of estimated income, $40 \%$ respondents stated that their organization estimated income ranging from RM300,000 to RM3 million and another $60 \%$ respondents stated that their organization estimated income ranging from RM300,000 to RM 15 million. Lastly, for the medium of the circulated annual report, 37.2\% respondents stated that their organization circulated annual report through email, followed by $27.9 \%$ each choose mail and website as the medium for circulating the annual report and lastly, $7.0 \%$ choose others as the medium for circulating the annual report.

\section{Normality Test}

Table 1: Test for Skewness and Kurtosis: Normality Test

\begin{tabular}{lcc}
\hline & Skewness & Kurtosis \\
\hline Social Value & -0.558 & -0.450 \\
Financial Value & -0.606 & -0.020 \\
Corporate Monitoring Process & -0.134 & -0.768 \\
Corporate Controlling Process & -0.042 & -0.783 \\
Corporate Structure & -1.013 & 0.669 \\
\hline
\end{tabular}

Based on Table 1 above, it shows the result for skewness and kurtosis analysis which was carried out for the purpose of normality test. Skewness is a measure of a symmetry. A data set is said to be symmetric if it looks the same to the left and right of the center. On the other hand, kurtosis is a measure of whether the data set are heavy-tailed or light-tailed in relation to a normal distribution. The acceptable value for skewness and kurtosis is within -2 to 2 George \& Mallery, 2010). The result 
INTERNATIONAL JOURNAL OF ACADEMIC RESEARCH IN BUSINESS AND SOCIAL SCIENCES

Vol. 10, No. 13, Special Issue: Upstream Research in Business and Management: Towards Socio-Economic Prosperity. 2020, E-ISSN: 2222-6990 @ 2020 HRMARS

for this data indicate that, the data is normally distributed since the value of skewness and kurtosis is within the acceptable range $(-1.013$ to -.606$)$ and $(0.669$ to $-.0 .783)$ respectively.

\section{Multicollinearity Test}

Table 2: Multicollinearity Test

\begin{tabular}{lcc}
\hline & N & VIF \\
\hline Corporate Monitoring Process & 86 & 2.987 \\
Corporate Controlling Process & 86 & 2.794 \\
Corporate Structure & 86 & 1.183 \\
\hline
\end{tabular}

Table 2 above represent the result for variance inflation factor (VIF). VIF analysis is used to assess the possible multicollinearity issue in the regression model. The VIF will identifies correlation between independent variables and the strength of that correlation. The result of VIF analysis shows the value range from 1.183 to 2.987 which suggest that there is no correlation between the variables, thus multicollinearity issue is not violated.

\section{Heterocedasticity Test}

Table 3: Heterocedasticity Test: Glejser Test

\begin{tabular}{lll} 
Model & & Sig. \\
\hline 1 & (Constant) & .024 \\
& Corporate Monitoring Process & .088 \\
& Corporate Controlling Process & .104 \\
& Corporate Structure & .841 \\
\hline
\end{tabular}

a. Dependent Variable: Social Value

\begin{tabular}{lll} 
Model & & Sig. \\
\hline 1 & (Constant) & .119 \\
& Corporate Monitoring Process & .906 \\
& Corporate Controlling Process & .999 \\
& Corporate Structure & .961 \\
\hline
\end{tabular}

a. Dependent Variable: Financial Value

Referring to the Table 3 above, it indicates the result for heteroscedasticity test using Glejser Test. The test is carried out to examine whether there is a difference in the residual variance of the observation period to another period of observation. Heteroscedasticity problem exist if the sig. 
INTERNATIONAL JOURNAL OF ACADEMIC RESEARCH IN BUSINESS AND SOCIAL SCIENCES

Vol. 10, No. 13, Special Issue: Upstream Research in Business and Management: Towards Socio-Economic Prosperity. 2020, E-ISSN: 2222-6990 @ 2020 HRMARS

value is $<0.05(\mathrm{Im}, 2000)$. From the table, it can be seen that the sig. value for all the variable is $>0.05$, indicating that there is no problem of heteroscedasticity and the data is proved to be homoscedastic.

\section{Reliability \& Validity Analysis}

Table 4: Reliability Statistics

\begin{tabular}{lcc}
\hline & Cronbach's Alpha & N of Items \\
\hline Social Value & 0.720 & 4 \\
Financial Value & 0.813 & 3 \\
Corporate Monitoring Process & 0.774 & 4 \\
Corporate Controlling Process & 0.758 & 4 \\
Corporate Structure & 0.859 & 9 \\
\hline
\end{tabular}

The purpose of the reliability test is to measure the consistency of the item developed in the questionnaire. The most common measure of reliability test is Cronbach's Alpha. In the Cronbach's Alpha, the acceptable and more suitable value is 0.7 (Kline, 2009). In the following sections, results of the statistical tests on the social value, financial value, corporate monitoring process, corporate controlling process and corporate structure were discussed. Meanwhile, the result of the Cronbach's Alpha is above 0.7, which shows acceptable reliability. Based on the guideline by Kline (2009), reliability of 0.7 or above was acceptable.

\section{Correlation Analysis}

Referring to Table 5, there are positive relationships between corporate monitoring process, corporate controlling process and corporate structure with social value and financial value. The correlation coefficients between all the variables are either strongly correlated or medium correlation.

Table 5: Pearson Correlation between Dependent Variables and Independent Variables $(N=86)$

\begin{tabular}{|c|c|c|c|c|c|}
\hline & $\begin{array}{l}\text { Social } \\
\text { Value }\end{array}$ & $\begin{array}{c}\text { Financial } \\
\text { Value }\end{array}$ & $\begin{array}{c}\text { Corporate } \\
\text { Monitoring } \\
\text { Process } \\
\end{array}$ & $\begin{array}{c}\text { Corporate } \\
\text { Controlling } \\
\text { Process }\end{array}$ & $\begin{array}{l}\text { Corporate } \\
\text { Structure }\end{array}$ \\
\hline Social Value & 1 & $.656^{* *}$ & $.334 *$ & $.641^{* *}$ & $.675^{* *}$ \\
\hline Financial Value & & 1 & .192 & .147 & $.662 * *$ \\
\hline $\begin{array}{c}\text { Corporate } \\
\text { Monitoring } \\
\text { Process }\end{array}$ & & & 1 & $.801 * *$ & $.342 *$ \\
\hline $\begin{array}{c}\text { Corporate } \\
\text { Controlling } \\
\text { Process }\end{array}$ & & & & 1 & $.256^{*}$ \\
\hline $\begin{array}{l}\text { Corporate } \\
\text { Structure }\end{array}$ & & & & & 1 \\
\hline
\end{tabular}

\footnotetext{
$* *$ significant at $5 \%(2$-tailed)
}

$* * *$ significant at $1 \%$ (2-tailed) 
INTERNATIONAL JOURNAL OF ACADEMIC RESEARCH IN BUSINESS AND SOCIAL SCIENCES

Vol. 10, No. 13, Special Issue: Upstream Research in Business and Management: Towards Socio-Economic Prosperity. 2020, E-ISSN: 2222-6990 @ 2020 HRMARS

Correlation between social value to each independent variables ranged from corporate monitoring process $(r=0.334)$, corporate controlling process $(r=0.641)$, and corporate structure $(r=0.675)$. Correlation for financial value to each independent variables ranged from corporate monitoring process $(r=0.192)$, corporate controlling process $(r=0.147)$, and corporate structure $(r=0.662)$. In summary, the results of the correlation test have provided a preliminary finding on a positive relationship between corporate monitoring process, corporate controlling process and corporate structure with social value and financial value. Therefore, these results have provided a preliminary evidence to support the objectives of this study.

\section{Multiple Regression Analysis}

The multiple regression analysis has been used to examine the effect of corporate monitoring process, corporate controlling process and corporate structure on the social value and financial value performance of the social enterprises. A separate multiple regression analysis is conducted to test the effect of the said independent variables on the social value (Table 6 ) and financial value (Table 7) performance of the social enterprises.

Table 6: Multiple Regression on Social Value $(N=86)$

\begin{tabular}{|c|c|c|c|c|c|c|c|}
\hline & Model & B & Std. Error & Beta & $\mathrm{t}$ & Sig. & VIF \\
\hline \multirow{11}{*}{1} & (Constant) & 1.323 & 0.525 & & 2.521 & 0.014 & \\
\hline & Corporate & 0.322 & & 0.356 & 2.667 & $0.009 * *$ & 2.987 \\
\hline & Monitoring & & & & & & \\
\hline & Process & & 0.121 & & & & \\
\hline & Corporate & -0.281 & & -0.321 & -2.483 & 0.015 & 2.794 \\
\hline & Controlling & & & & & & \\
\hline & Process & & 0.113 & & & & \\
\hline & Corporate & 0.642 & & 0.604 & 7.184 & $0.000 * * *$ & 1.183 \\
\hline & Structure & & 0.089 & & & & \\
\hline & Model F-statistic & 10.336, & $p$-value & .000 & & & \\
\hline & R-square & .517 & $\begin{array}{l}\text { Adjusted } \\
\text { R-square }\end{array}$ & .493 & & & \\
\hline
\end{tabular}

**significant at $5 \%$ (2-tailed)

$* * *$ significant at $1 \%(2$-tailed) 
INTERNATIONAL JOURNAL OF ACADEMIC RESEARCH IN BUSINESS AND SOCIAL SCIENCES

Vol. 10, No. 13, Special Issue: Upstream Research in Business and Management: Towards Socio-Economic Prosperity. 2020, E-ISSN: 2222-6990 @ 2020 HRMARS

Table 7: Multiple Regression on Financial Value

\begin{tabular}{|c|c|c|c|c|c|c|c|}
\hline & Model & \multicolumn{3}{|c|}{ Std. } & $\mathrm{t}$ & Sig. & VIF \\
\hline & (Constant) & 0.663 & 0.669 & & & & \\
\hline & Corporate & -0.059 & 0.154 & -0.055 & -0.384 & 0.702 & 2.987 \\
\hline & Monitoring & & & & & & \\
\hline & Process & & & & & & \\
\hline \multirow[t]{7}{*}{1} & Corporate & 0.017 & 0.144 & 0.016 & 0.115 & 0.909 & 2.794 \\
\hline & Controlling & & & & & & \\
\hline & Process & & & & & & \\
\hline & Corporate & 0.845 & 0.114 & 0.671 & $7.429 * * *$ & $0.000 * * *$ & 1.183 \\
\hline & Structure & & & & & & \\
\hline & Model F-statistic & 12.350 & $p$-value & .441 & & & \\
\hline & $p$-value & .000 & $\begin{array}{l}\text { Adjusted } \\
\text { R-square }\end{array}$ & .413 & & & \\
\hline
\end{tabular}

$* * *$ significant at $1 \%(2$-tailed)

The first hypothesis is to examine the effect of corporate monitoring process on performance of the social enterprises. For the $\mathrm{H} 1 \mathrm{a}$ which is to observe the relationship between corporate monitoring process and social value, based on the result in Table 2, the coefficient for corporate monitoring process is $.322, t=2.667, p=.702$ where $p<.05$ indicates that the result has supported the H1a. The beta coefficient for corporate monitoring process (.322) indicates that for every 1 rise in the corporate monitoring process could influence the performance of the organization by .322. For the $\mathrm{H} 1 \mathrm{~b}$ as referred to Table 3, which is to observe the relationship between corporate monitoring process and financial value, the coefficient for corporate monitoring process is $-.059, t=-.384, p=.702$ where $p>.05$ indicates that this result does not support the H1b. This result shows that, there is no effect whether the organization has a good corporate monitoring process or not towards the financial value.

The second hypothesis is to observe the effect of corporate controlling process on performance of the social enterprises. For the $\mathrm{H} 2 \mathrm{a}$ which is to observe the relationship between corporate controlling process and social value, based on the finding in the Table 2 coefficient for corporate controlling is at $-.281, \mathrm{t}=-2.483, \mathrm{p}=.015$ where $\mathrm{p}<.05$ indicates a significant negative relationship between the controlling process and social value. The beta coefficient for corporate controlling process (-.321) indicates that for every 1 rise in the corporate controlling process could decrease the social value by -.0321 . This result is not supported $\mathrm{H} 2 \mathrm{a}$. For the $\mathrm{H} 2 \mathrm{~b}$ as referred to Table 3 , which is to observe the relationship between corporate controlling process and financial value, the coefficient for corporate controlling process is .017, $t=.115, p=.909$, where $p>.05$. Therefore, the result also does not support $\mathrm{H} 2 \mathrm{~b}$. 
INTERNATIONAL JOURNAL OF ACADEMIC RESEARCH IN BUSINESS AND SOCIAL SCIENCES

Vol. 10, No. 13, Special Issue: Upstream Research in Business and Management: Towards Socio-Economic Prosperity. 2020, E-ISSN: 2222-6990 @ 2020 HRMARS

The last hypothesis is to observe the effect of corporate structures on the performance of the social enterprises. For $\mathrm{H} 3 \mathrm{a}$, which is to observe the relationship between corporate structure and social value, based on the finding in the Table 2 , the coefficient for corporate structure is at .642, $\mathrm{t}=$ 7.184, $p=.000$ where $p<.01$ indicates that this result supported the third hypothesis, H3a. The beta coefficient for corporate structure (.604) indicates that for every 1 rise in the corporate structure .604 will increase the social value. For $\mathrm{H} 3 \mathrm{~b}$ as referred in Table 3, which is to observe the relationship between corporate structure and financial value, the coefficient for corporate structure is .845 , $t=7.429$, and $p=.000$, where $p<.01$ indicates that this result also supported the H3b.

\section{Discussion of the Findings}

The minimal research in the corporate governance practices and performance of the social enterprises in Malaysia is one of the main reasons for this study to be conducted. The dependent variable of the study is the performance of the social enterprises, which are viewed from the perspectives of social value and financial value. This is because according to Zainon et al. (2014), the aim of social enterprise is to create blended return on investment which is an integration return of financial investment, social, environmental and cultural. Meanwhile, the independent variable of the study is to corporate governance practices that comprises of corporate monitoring process, corporate controlling process and corporate structure. Three objectives and six hypotheses were developed in order to investigate the effect of corporate monitoring process, corporate controlling process and corporate structure on the social value and financial value performance of the social enterprises in Malaysia.

The first objective is to examine the effects of corporate monitoring process on the social enterprises' performance and two hypotheses, $\mathrm{H} 1(\mathrm{a})$ and $\mathrm{H} 1$ (b) was developed. $\mathrm{H} 1$ (a) suggested that there is a positive effect of corporate monitoring process on the social value. The results obtained in this study showed a positive relationship between both variables (corporate monitoring process and social value), thus indicates that through monitoring process, more social needs and social problems can be solved by the social enterprises. A study by Lipiper, Lajh and Gric (2013) stated that through monitoring process, it enables the organization to improve their performance and wider its impact to the various stakeholder. Therefore, it is assumed that through monitoring process, more beneficiaries will be served by the social enterprises. However, $\mathrm{H} 1$ (b) that examined the effect of corporate monitoring process on the financial value was not supported. Thus, this finding indicated that the corporate monitoring process would not have an impact on the financial profitability of the social enterprises. The contradict result between $\mathrm{H} 1(\mathrm{a})$ and $\mathrm{H} 1$ (b) might be due to inherent challenge of operating social enterprise whereby the organization needs to balance both their social and financial mission. The challenge is also known as mission drift. In real business practice, the process of generating both social and financial value means decisions and actions are in frequent opposition. For example, in the case where the organization mission is skewed towards social mission, the monitoring process also will be skewed more towards social mission instead of financial mission (Conforth, 2014).

The second objective is to examine the effects of corporate controlling process on the social enterprises' performance and two hypotheses, $\mathrm{H} 2(\mathrm{a})$ and $\mathrm{H} 2(\mathrm{~b})$ was developed. $\mathrm{H} 2(\mathrm{a})$ suggested that there is a positive effect of corporate controlling process on the social value. Meanwhile, $\mathrm{H} 2(\mathrm{~b})$ also suggested that there is a positive effect of corporate controlling process on the financial value. The 
INTERNATIONAL JOURNAL OF ACADEMIC RESEARCH IN BUSINESS AND SOCIAL SCIENCES

Vol. 10, No. 13, Special Issue: Upstream Research in Business and Management: Towards Socio-Economic Prosperity. 2020, E-ISSN: 2222-6990 @ 2020 HRMARS

result showed a significant effect but in a negative relationship between the controlling process and social value in which not supported the $\mathrm{H} 2(\mathrm{a})$. This finding could be justified as according to Merwe (2011), with more control, managers may operate the organization for the benefit of their own interest and not organization's interest. In addition, a study by Claessens et al. (2002) also finds that control by management has a purely harmful effect on firm value from a sample of East Asian firms. On the other hand, there is a positive relationship found between corporate controlling process and the financial value however, it is not significant. Therefore, $\mathrm{H} 2(\mathrm{~b})$ is not supported. This finding further supports the findings found by Bowrin (2004) as he also found that social enterprises in Trinidad and Tobago especially in religious organization having inadequate and patchy corporate controlling process thus do not give any influence towards the performance of social enterprises. Therefore, it is implicit that controlling process is either negatively or not related to the social value and financial value of the social enterprises due to the possibility of self-interest or opportunistic behavior by the management.

The third objective is to examine the effects of corporate structure on the social enterprises' performance and two hypotheses, $\mathrm{H} 3(\mathrm{a})$ and $\mathrm{H} 3(\mathrm{~b})$ was developed. $\mathrm{H} 3(\mathrm{a})$ suggested that there is a positive effect of corporate structure on the social value. Meanwhile, $\mathrm{H} 3(\mathrm{~b})$ suggested that there is a positive effect of corporate structure on the financial value. The findings of this study showed a positive significant relationship for both hypothesis, thus both hypotheses were supported. Therefore, it is proved that the boards are important in providing access to various resources and strategic advice to help managers in achieving their profit maximization goals (Pearce and Zahra, 1992; Pugliese et al., 2009). In addition, Mswaka and Aluko (2015) also stated that the role of the board of directors is crucial for the performance of the social enterprise. Apart from profit maximization goals, the results of the study also showed that through a proper corporate structure, the social enterprises are able to accomplish their social mission of dealing with the various social problems.

\section{Conclusion}

This study is conducted to provide further understanding on corporate governance practices of the Malaysian social enterprises and how the practices could affect the performance. Specifically, this study examined the effects of corporate monitoring process, corporate controlling process and corporate structure on the social enterprises' social value and financial value. Based on the results from this study, there are few contributions to respective parties such as practitioners, academia/researchers and the regulators. For the practitioners, they can use these findings as to understand how the corporate monitoring process, corporate controlling process and corporate structure could help them to improve their performance. It is important for social enterprises to implement a proper corporate governance practices in order to ensure the accomplishment of social and financial objectives. Therefore, the findings can help the social entrepreneurs to measure their performance through an observation of the corporate governance practices established and managed by them. As for the academia, this study could provide them with the latest literature that relates to this limited research area in Malaysia. Hence, it helps to increase and expand the evidences regarding the corporate governance practices specifically in the social enterprises sector. In addition, it is hoped to encourage more research in the field of social enterprises in Malaysia. However, there are some limitations to be noted. Firstly, as the prior researches on the corporate governance of the 
INTERNATIONAL JOURNAL OF ACADEMIC RESEARCH IN BUSINESS AND SOCIAL SCIENCES

Vol. 10, No. 13, Special Issue: Upstream Research in Business and Management: Towards Socio-Economic Prosperity. 2020, E-ISSN: 2222-6990 @ 2020 HRMARS

social enterprises in Malaysia is minimal, there is not enough evidences available to describe the importance of corporate governance towards enhancing the social enterprises' performance. Secondly, the response rate of this study is low due to many of the respondents are giving no response to the questionnaires. Therefore, the results of this study could be used to generalize the findings to all listed social enterprises in Malaysia. Lastly, as this study is using questionnaire as the research instrument, the results are based on the data collected and this may affect the accuracy of the answer. Therefore, the answers provided by the respondents might not really reflect the real corporate governance practices of the social enterprises. On the other hand, more research related to this topic with different variables could be carried out for future researches. In addition, there are not many studies, which examine the concept and development of social enterprises in Malaysia, thus, this provide some opportunities for future research.

\section{Acknowledgements}

The authors gratefully acknowledge the help of the Ministry of Higher Education of Malaysia in providing the FRGS research grant and Universiti Teknologi MARA, Malaysia.

\section{References}

Bagnoli, L., \& Megali, C. (2011). Measuring performance in social enterprises. Nonprofit and Voluntary Sector Quarterly, 40(1), 149-165. https://doi.org/10.1177/0899764009351111

Bahari, M. A. K. A., \& Suhaimi, M. S. (2016). Social entrepreneurship, social entrepreneur and social enterprise: A review of concepts, definitions and development in Malaysia. Journal of Emerging Economies and Islamic Research, 4(2), 16. Retrieved from www.jeeir.com

Bhatt, P. R., \& Bhatt, R. R. (2017). Corporate governance and firm performance in Malaysia. Corporate Governance: The International Journal of Business in Society, 17(5), 896-912. https://doi.org/10.1108/CG-03-2016-0054

Bowrin, A. R. (2004). Internal Control in Trinidad and Tobago Religious Organizations. Accounting, Auditing \& Accountability Journal, 17(1), 121-152. https://doi.org/10.1108/09513570410525238.

Cornforth, C. (2014). Understanding and combating mission drift in social enterprises. Social Enterprise Journal, 10(1), 3-20

Crucke, S., \& Decramer, A. (2016). The Development of a Measurement Instrument for the Organizational Performance of Social Enterprises. Sustainability, 8(2), 161. https://doi.org/10.3390/su8020161

Eker, M., \& Eker, S. (2016). The effects of interactions between management control systems and strategy on firm performance: an empirical study. Business and Economics Research Journal, 7(4), 123-141.

Fadeyi, O. (2016). Impact of Organizational Structure on Organizational Performance, (January).

Fiskovi, C. (2013). Controlling And Business Efficiency, 4, 44-52.

George, D., \& Mallery, M. (2010). SPSS for Windows Step by Step: A Simple Guide and Reference, 17.0 update (10a ed.) Boston: Pearson.

Halim, E. H., Mustika, G., Sari, R. N., Anugerah, R., \& Mohd-Sanusi, Z. (2017). Corporate governance practices and financial performance: The mediating effect of risk management committee at 
INTERNATIONAL JOURNAL OF ACADEMIC RESEARCH IN BUSINESS AND SOCIAL SCIENCES

Vol. 10, No. 13, Special Issue: Upstream Research in Business and Management: Towards Socio-Economic Prosperity. 2020, E-ISSN: 2222-6990 @ 2020 HRMARS

manufacturing firms. Journal of International Studies, 10(4), 272-289. doi:10.14254/2071$8330.2017 / 10-4 / 21$.

Im, K. S. (2000). Robustifying Glejser test of heteroskedasticity. Journal of Econometrics. 97: 179

Kallamu, B. S., \& Saat, N. A. M. (2015). Audit committee attributes and firm performance: evidence from Malaysian finance companies. Asian Review of Accounting, 23(3), 206-231. https://doi.org/10.1108/ARA-11-2013-0076

Lipiper, S., Lajh, D., \& Gric, I. (2013). Monitoring Systems of Good Governance. Centre for Political Science Research, 355-356.

Low, C. (2006). A framework for the governance of social enterprise. International Journal of Social Economics, 33(5/6), 376-385. https://doi.org/10.1108/03068290610660652

MCCG. (2017). Malaysian Code on Corporate Governance. Retrieved from https://www.sc.com.my/wp-content/uploads/eng/html/cg/mccg2017.pdf

Merwe, M. (2011). Policy on governance oversight and management control, 2-5.

Mokhtar, S. A., Abdullah, M., \& Kin, D. T. Y. (2014). A Conceptual Framework for Social Entrepreneurship in Malaysia. International Journal of Contemporary Business Management, 1(1), 52-62.

Mswaka, W., \& Aluko, O. (2015). Corporate governance practices and outcomes in social enterprises in the UK A case study of South Yorkshire, 1-18.

Nizam, S. (2017). Public Interest Corporation : A New Business Platform for Social Entrepreneurship in Malaysia, Social Sciences \& Humanities 25, 129-134.

Rizam, M., Abdullah, S., \& Abdulsomad, K. (2017). a Concept in Promoting Social Entrepreneurship Through Malaysian Innovation and Creativity Centre for Sustainability Economic, 8(1), 105-109.

Son, H., Lee, J., \& Chung, Y. (2017). Value Creation Mechanism of Social Enterprises in Manufacturing Industry: Empirical Evidence from Korea. Sustainability, 10(1), 46. https://doi.org/10.3390/su10010046

Sidek, S. F. M. Y. A. N. M., Mobidin, H. Z., \& Adam, S. N. A. (2018). Big Data towards DecisionMaking Culture in Organization. International Journal of Academic Research in Progressive Education and Development, 7(3), 103-115.

Spear, R., Cornforth, C., \& Aiken, M. (2009). The governance challenges of social enterprises: Evidence from a UK empirical study. Annals of Public and Cooperative Economics, 80(2), 247-273. https://doi.org/10.1111/j.1467-8292.2009.00386.x

Tyasari, I., Yusof, N. Z. M., Bahador, K. M. (2018). Indonesia's Participation in ASEAN Audit Regulators Group (AARG): Efficiency-driven or Institutional Pressure? International Journal of Academic Research in Accounting, Finance and Management Sciences 8 (3): 299-309.

Vrettou, A. (2014). The "Very Successful L2 Learner" In The Sixth Grade Of The Greek Elementary School As Portrayed Through A Qualitative Study. Multilingual Academic Journal Of Education And Social Sciences, 2(2), 1-14.

Zainon, S., Ahmad, S. A., Atan, R., Wah, Y. B., Bakar, Z. A., \& Sarman, S. R. (2014). Legitimacy and Sustainability of Social Enterprise: Governance and Accountability. Procedia - Social and Behavioral Sciences, 145, 152-157. https://doi.org/10.1016/j.sbspro.2014.06.022 